\title{
Technoecologies of Borders: Thinking with Borders as Multispecies Matters of Care
}

\author{
Josef Barla \& Christoph Hubatschke
}

To cite this article: Josef Barla \& Christoph Hubatschke (2017) Technoecologies of Borders: Thinking with Borders as Multispecies Matters of Care, Australian Feminist Studies, 32:94, 395-410, DOI: $10.1080 / 08164649.2017 .1466648$

To link to this article: https://doi.org/10.1080/08164649.2017.1466648
(2) 2018 The Author(s). Published by Informa UK Limited, trading as Taylor \& Francis Group

Published online: 09 May 2018.

Submit your article to this journal

Џلll Article views: 535

View Crossmark data $\asymp$ 


\title{
Technoecologies of Borders: Thinking with Borders as Multispecies Matters of Care
}

\author{
Josef Barla (1) ${ }^{a}$ and Christoph Hubatschke (i) ${ }^{b}$ \\ ${ }^{\mathrm{a}}$ Faculty of Social Sciences, University of Vienna, Vienna, Austria; ${ }^{\mathrm{b}}$ Department of Philosophy, University of \\ Vienna, Vienna, Austria
}

\begin{abstract}
Reading Félix Guattari's concept of ecology through feminist accounts of care and solidarity, and vice versa, in this article, we propose the concept of feminist technoecology as a speculative mode of thinking with borders. Rather than considering borders as lines on maps or primarily as physical arrangements, we argue that feminist technoecology allows for an understanding of borders as multispecies matters of care where cuts that matter are enacted, and precisely therefore calls for transversal solidarity and care that goes beyond the human. Turning to two stories revolving around the naturalisation of borders, bodies, and territories, we demonstrate that a technoecological take on borders not only fundamentally questions an a-priori distinction between technology, ecology, geology, politics, bodies, and a more-than-human world, but also foregrounds different modes of attentiveness with regard to questions of care, nativity, and mattering.
\end{abstract}

\section{Introduction}

Satellites surveying suspicious movements from their orbit, illuminated high-security borderlines between states that can be seen from space, and drones spotting small boats on the sea seem to suggest that borders have become technological borders. Even though it could be argued that borders have always been technological - from the first marches and wooden walls to protect Neolithic settlements to the hightech, barbed wired fences today - not only the quality and intensity of the technologisation of borders but also their form and function has historically changed. In today's control societies, borders have also become abstract codes, sophisticated algorithms, and digital barriers. New phenomena such as biometric passports or DNA and isotope tests employed as technological and technoscientific means for reading off supposed truths about the identity, the ethnicity, and even the nationality from the bodies of migrants and travellers demonstrate this. These technologies and technoscientific practices further relocate physical borders deep into bodies, exercising surveillance from within. However, not only has the form and function of borders changed in 
control societies but also migration and even having a body has become a different meaning, as the body itself has been transformed into a source of truth in the process of migration and border control.

It is more than just a coincidence that the notion of the border, particularly in German and Slavic languages, has a strong etymological connection with the organic. Etymologically, the word 'border' derives from the Proto-Indo-European root '*bherdh-' and means 'to cut'. In both Old Indian and Old Greek, but also in Latin, 'to cut', 'to threaten', 'to destroy', and 'to pillage' share the same root, namely '*bherdh-' or 'bhren-'. ${ }^{1}$ Interestingly, despite its Germanic roots, the modern German word for border, 'Grenze', is of Slavic origin. The Polish word 'granica' derives from the Slavic word 'grana' for branch or path and the Indo-European word 'ghre' for green and for growing or proliferating. Not only the etymological roots of the notion of the border that associate it with cuts, proliferation, and enactments, remind us that borders are in several ways cuts, wounds left on the earth and on human and nonhuman bodies. From the first ancient marches and the cornerstones covered in the guts and the blood of animals that were used to mark the earth, the border as a naturalcultural phenomenon, too, aimed at cutting, threatening, and binding the vital forces and existential flows of human and more-than-human life, subjugating them under the laws and calculations of bio- and necropolitics. ${ }^{2}$

Departing from the idea that how borders are understood affects the ways in which it is cared for what happens at the border and beyond to whom and why, in this article, we propose feminist technoecology as a form of speculative thinking that explores into the relationalities, the knots and the cuts, that are brought to the fore when engaging with stories of borders. Feminist scholars have been at the forefront in emphasising the ethics and politics of care. Initially referring to labour done in service of others, often but not necessarily in the context of reproductive work, over the last decades the notion and practice of care 'has been expanded and challenged from a range of perspectives that go well beyond activities traditionally and socially identified as women's work' (Puig de la Bellacasa 2017, 2). Informed by these debates, we argue that caring is about involvement as much as about intervention in practices of knowing and doing. Against this backdrop, the conception of feminist technoecology as a diffractive lens ${ }^{3}$ for speculative encounters with borders that we propose here, not only affects ways of producing knowledge about borders, boundaries, and bodies (human and nonhuman ones alike), but also affects those who are researching questions of care and mattering. As a speculative mode of thinking, feminist technoecology attaches to a feminist body of work for which the speculative as a mode of thought is about 'provoking political and ethical imagination in the present' (Puig de la Bellacasa 2017, 7) in the search for more liveable futures for everyone. As the stories and futures, such a speculative thinking engages with cannot be about humans alone, feminist technoecology works toward an understanding of borders as multispecies entanglements involving a number of heterogeneous actors.

Turning to the philosophy of Félix Guattari and reading it through feminist accounts of care and solidarity, in what follows, we will not only unpack the many-layered meaning of ecology in technoecology but also propose a shift from 'transversal thinking' to 'transversal politics' to what we call 'feminist transversal solidarity' - which, as we argue, is closely tied to a politics of becoming with and caring for the other that lies at the heart of our account of feminist technoecology. 


\section{Feminist transversal solidarity and technoecological care}

Drawing on Gregory Bateson's work, in The Three Ecologies, Félix Guattari proposes an extended understanding of ecology as an assemblage of 'social', 'mental', and 'environmental' (Guattari 1989, 34) forces and flows which are not only traversed through but also constituted by technology. It is for this very reason that, for Guattari, technology cannot be separated from ecology. Guattari's concept of ecology, far from merely referring to a particular idea of the environment, 'questions the whole of subjectivity and capitalistic power formations - formations which, moreover, can by no means be assured of continuing their success of the last decade' (140). It is against this backdrop that Guattari, in collaboration with Gilles Deleuze, foregrounds the notion of the 'mechanosphere' (Deleuze and Guattari 2004, 77) in order to shift the focus to complex machinic assemblages that is, to relationalities of heterogeneous human and more-than-human forces and flows which constantly constitute and reconfigure one another. 'There is no such thing as either man or nature', they argue, but 'only a process that produces the one within the other and couples the machines together. Producing-machines, desiring-machines everywhere, schizophrenic machines, all of species life: the self and the non-self, outside and inside, no longer have any meaning whatsoever'. (Deleuze and Guattari 1983, 2) ${ }^{4}$

The notion of ecology has repeatedly invoked images and imaginations about the undamaged, the unspoiled, the pure, and the whole. Guattari, too, is not fully able to break with these associations. This is, for example, the case when Guattari suggests that

the maintenance of natural equilibria will be dependent upon human intervention; the time will come, for example, when massive programmes will have to be set in train to regulate the relationship between oxygen, ozone, and carbon dioxide in the earth's atmosphere. (Guattari 1989, 146)

Guattari goes even as far as to argue that we 'need much more than a mere defence of nature. If the Amazonian "lung" is to be regenerated, the Sahara desert made fertile again' (Guattari 1989, 146). In so arguing, Guattari runs the risk of reinstating the idea of a pure, technologically and culturally untouched original nature or equilibrium which not only can get lost but also ironically technologically restored as an actual, physical site. Guattari is by far not the only one who evokes a rather problematic understanding of a pure nature and a supposed natural balance. In fact, these ideas are still underlying many contemporary discourses on ecology and environmental politics in science and popular culture. Yet we believe that, if read transversally through feminist accounts of care and solidarity, Guattari's concept of ecology can provide an important point of departure toward what we call a 'technoecological reading of borders'.

Closely tied to his concept of ecology, Guattari ([2015] 1964) introduced the notion of 'transversality' as an ethico-political concept that aims at connecting traversing differences as well as fundamentally heterogeneous parts. Particularly, but not only, with regard to ecological questions, for Guattari, thinking and acting transversally promises to revive solidarity between heterogeneous actors. Influenced by the ethico-political philosophy of Guattari as well as feminist coalition politics, Nira Yuval-Davis develops the concept of 'feminist transversal politics', offering a way to move beyond individualism and identity politics. Bringing together feminist activism and theory, Yuval-Davis' account of feminist transversal politics works as a multilayered political strategy that gathers heterogeneous 
positions and standpoints, and aligns them toward shared political struggles. As such, feminist transversal politics marks a process of 'rooting and shifting' (Yuval-Davis 2006, 282) that aims at cultivating care and solidarity in order to comprehend marginalised positions without speaking from those very positions. In her recent work on migration, Yuval-Davis employs her concept of feminist transversal politics as an intersectional tool for evading thinking along the categories of nativity and 'otherness' by proposing a 'transversal us' (Yuval-Davis 2010, 277). For Yuval-Davis, transversal politics works not only 'as an alternative to identity politics' but also aims at 'establishing a collective "us", across borders and boundaries of membership, based on solidarity with regard to common emancipatory values'. (277-278) Even though Yuval-Davis' avoids breaking down shared struggles at and beyond borders by establishing a collective, transversal 'us', in an important sense, solidarity remains restricted to humans.

Remaining faithful to Yuval-Davis feminist politics and returning to Guattari's extended notion of ecology, ${ }^{5}$ we believe that a more inclusive account of transversal solidarity is both possible and necessary. Genealogically, the notion of solidarity shares not only an association with 'density' and the idea of being 'undivided', but is also related to affinity, connectedness, kin, and mutual responsibility. A 'feminist transversal solidarity' hence can be understood as a form of solidarity that binds together humans and nonhumans in shared struggles. Solidarity here is about the micropolitical practices of assembling, connecting, and recomposing as much as about accountability and responsibility for what matters as well as for what is excluded from mattering. The notion of care that derives from such an account of solidarity refers to a being with and through the other, binding together the idea of a radical vulnerability with the call for attentiveness to shared struggles and connections by affinity. In an important sense, such an understanding might also open up the way for an understanding of borders as multispecies matters of care. Following Puig de la Bellacasa (2011) the notion of 'matters of care' denotes an ethico-political concept and a practice for highlighting the neglect of caring relationalities. Re-presenting something as a matter of care means intervening into politically and ethically demanding questions and issues through responsible ways of producing knowledge. In a world of relations, thinking with care, thus, marks a feminist practice that,

compels us to look at thinking and knowing from the perspective of how our cuts foster relationship, more than how they isolate figures. This allows looking at "cuts" from the perspective of how they are re-creating, or being created by "partial connections". (Puig de la Bellacasa 2012, 20)

Rather than just explaining what a given phenomenon is and how it came into being, concepts are also about participating and intervening in the possible becoming of phenomena, or what following Haraway and Puig de la Bellacasa might be called a 'passionate construction' of relations. Even though caring as relating can express an asymmetry of power, it also 'connotes attention and worry for those who can be harmed by an assemblage but whose voices are less valued, as are their concerns and need for care' (Puig de la Bellacasa 2011, 92). It is for this very reason that the notion of borders as matters of care that arises from a feminist reading of Guattari embodied in the concept of a transversal solidarity, involves a sense of attachment of and involvement into what happens at and through borders. 
Informed by these insights, a conception of feminist technoecology as a speculative mode of thinking comes to the fore that perhaps implies even more associations with the vital forces and flows than the rather technical notions 'assemblage' and 'entanglement'. While ecology is conceived as a chain of naturalcultural relationalities, technology - rather functioning as the Other to the lived body - is understood as what can be called by expanding on Jacques Derrida and Gilbert Simondon 'originary technicity'. ${ }^{6}$ Allowing for capturing the iterative intra-active ${ }^{7}$ entanglements of the biological, the geological, the technological, and the political in power/knowledge/matter formations, speculatively thinking with the concept of feminist technoecology, as we will demonstrate, shifts the attention to relationalities and processes of becoming-with as caring for the other. In doing so, borders become 'readable' as multispecies matters of care composed of and stabilised through entangled human and nonhuman bodies, technologies, geologies, politics, and discourses. At the same time, however, borders are not only regarded as cuts themselves but also as continuously enacting cuts 'that demand and enable response' (Haraway 2008, 71).

In speculatively thinking with the concept of feminist technoecology, in what follows, we will stay with the trouble ${ }^{8}$ and focus on two different yet somehow also kindred stories of borders that revolve around the naturalisation of territories, borders, and bodies, issues of becoming-with, as well as the question of mattering and caring.

\section{Stories from the border}

\section{Purified nature(s)? alien species as refugees}

In an interview in the Austrian newspaper Profil on 6 September 2016, the Austrian minister of internal affairs, Wolfgang Sobotka, suggested that refugees should do community service for no or extremely low wages, while they are waiting for their asylum application to be processed. One way how refugees could support the local community, Sobotka suggested, would be in helping eradicating so-called alien or invasive species - mainly plants - which are not native to domestic ecosystems, ${ }^{9}$ and thus seen as potentially harmful. This is not an entirely new suggestion as there already exist projects involving refugees doing environmental work in Austria and Germany. Obligating, of all people, refugees to help eradicating so-called invasive species in border regions is, as we want to argue here, more than only a coincidence, more than only a rhetorical similarity. Rather, this practice exemplifies the entangled nature of current borders, the embodiment of borders both in human and nonhuman bodies, defining who or what is accepted, and seen as native, and who or what is defined as alien, invasive, and foreign - and thus as the Other to the naturalised native community, ecosystem, or nation state. ${ }^{10}$

Over the last few years, many parts of the world have witnessed an immense intensification and fortification of national borders. Besides the serious consequences national borders can have for humans, especially refugees, these intensified border zones can also have tremendous impacts on ecosystems and nonhumans. Be it bison herds at the US-Mexico border, which are cut off from their food sources through the border wall (Schlyer 2012, 2), be it herds of elephants which got confused after the closure of the Indian-Pakistan border, leading to attacks against villages, or be it plants in the USMexican border zone, which do not get enough water because of the border wall blocking 
rivers and redirecting the water (see Jones 2016, 215-217), to name but a few examples. Border walls, barbed wired fences, and mined border zones affect species in different ways. A recent example for this can be found in the newly erected border fence between Slovenia and Croatia, where nearly the whole border got fortified with barbed wired fences, with a serious effect for local wildlife - particularly bears, lynx, and wolves. Many of these species were just resettled a few years ago after nearly going extinct. Aiming at cutting off the so-called 'Balkan route' - a route mainly used by Syrian refugees leading from Turkey to Greece and all the way up to Germany and Sweden - these newly erected borders now threaten both refugees fleeing war and the local wildlife (see Neslen 2016).

In the age of global capitalism, the constant acceleration of the movement of goods and people also led to an acceleration of the spreading of so-called non-native plants and animals into new territories. In some ecological and biological studies - particularly in invasive ecology - alien species are defined as species not common or native to a particular ecosystem. ${ }^{11}$ Be it deliberately or unnoticed, most alien species arrived in their new habitats through human activities. Until the first half of the twentieth century, the migration of nonhuman species was rarely a concern for biologists but a common practice. Often, alien species were introduced through imperialistic and colonialist expansions, as, for example, Alfred Crosby has analysed in Ecological Imperialism (1987) by looking at colonial planting practices in Australia. The rise of temperatures, floating garbage patches of the size of entire countries in the oceans, and an advancing urbanisation of once sparsely populated regions, however, have led to a dramatic increase in the numbers of species 'fleeing' from their native habitats, thus becoming 'refugee species'. Especially in remote islands or fragile ecosystems, the introduction of these new species can have devastating consequences, affecting whole ecosystems. Alarmed by consequential changes in some ecosystems as well as the extinction of native species, a new spectre began to haunt ecological studies, namely the spectre of the 'invasive species'.

The term invasive species was popularised by the British zoologist Charles Elton in The Ecology of Invasions by Animals and Plants (1958). In this founding work of invasion ecology, Elton not only collected different examples of invasive species all around the world, but also introduced many militaristic sounding terms for describing them as 'invaders'. The extent to which Elton's thinking and rhetoric were deeply rooted in the time of the Cold War, is already revealed by the very first sentences of his book.

Nowadays we live in a very explosive world, and while we may not know where or when the next outburst will be, we might hope to find ways of stopping it or at any rate damping down its force. It is not just nuclear bombs and wars that threaten us, though these rank very high on the list at the moment: there are other sorts of explosions, and this book is about ecological explosions. (Elton 1958, 15)

Elton however was not the first to talk about alien species in this harsh and militaristic tone. Some of the first works engaging with 'foreign species' were written by ecologists from Nazi-Germany during the Second World War, which categorised in their work nonnative, meaning 'non-Aryan' plants (Barbour 1996, 2). Driven by a fascist understanding of Social Darwinism, botanists like Reinhold Tüxen propagated the need for a 'cleansing' and a 'purification' of the German landscape as well as of its people (Gould 1998, 3).

Although current invasion ecology is by no means fascist or xenophobic per se, it has to be noted that the metaphors used to describe alien species, as well as the rhetoric how 
one has to deal with these species often remains unreflected and therefore problematic. The descriptions of alien species bare uncanny similarities to racist and white supremacist characterisations of refugees. Despite that only a few percentage of all the species that are considered as the alien can also be categorised as invasive (Pearce 2015, 150), ${ }^{12}$ the term alien species is often used synonymously with the term invasive species - which then are often characterised as aggressive and dominant. The image of alien species in both research and popular culture is frequently rooted in political crises of the time, be it fascism, the Cold War, today's refugee crisis, or the fear of fundamental changes in environmental systems through climate change.

Drawing on feminist technoecology as a diffractive lens for a speculative thinking with borders as multispecies matters of care where cuts that matter are enacted not only questions the very distinction between the native self and the invading other, but also shifts the focus to complex entanglements characterised by openness and movement, rather than fixation. In doing so, such an account fundamentally breaks with the naturalisation of borders and bodies, of territories and kinship. In this light, obligating refugees to help eradicating so-called invasive species has to be understood as part of a ubiquitous politics of bordering. Both refugees as well as invasive species are mutually hailed into being as the other, the foreign, the alien, and the invader, that has to be eradicated, shipped back to their country of origin, or has to be stopped to enter a particular country respectively ecosystem in the first place. The double bind of refugees as being categorised and policed as 'aliens' and as being forced to work without proper payment is another border policing. It is in this light that calls for eradicating invasive species 'cuts together-apart' humans, nonhumans, and territories. Not only paths for fleeing are cut off but also, in a very literal sense, the roots of those defined as the other. Life becomes subjugated under a politics of the distribution of death, the politics of abandoning lives - namely, the lives of the human and nonhuman others. It is in this sense that the very notion of the invader 'makes killable, whether you're talking about immigrants from Central America or rats and cats on an island. "Invasive species" is, literally, a powerful way to make killable' (Haraway 2016b, 225). In a sense, the notion of 'invasive species' thus also enacts another border, one that differentiates life from death.

But it is exactly also here, in the 'existential territories' (Guattari) of current border zones, where species meet - refugees without refuge, forced to live in border zones, forced to be the border, forced to be out of 'their' place, constantly exposed to the cuts the border enacts. Alien species are rooted in their new habitats, connected to the soil, nurturing from the very same soil as supposed 'native species', yet they remain foreign, they remain 'invaders'. Even though some of these species are 'native' to the ecosystems for hundreds of years - meaning that they migrated or were introduced by humans to certain areas of the world long before biologists invented the category of invasive species - they are still categorised and considered as alien. In an important sense, the question is not only who is seen as native and who is categorised as alien, but also how precarious life is integrated into the political economy as well as into hegemonic power relations. From underpaid migrant workers in agriculture and other sectors, to exotic alien species introduced for special purposes, so-called 'non-natives' are only tolerated as long as they can be exploited. Subramaniam $(2001,35)$ reminds us that as long 'nonnatives' 
know their rightful place as workers, laborers, and providers, and controlled commodities, their positions manipulated and controlled by the natives, their presence is tolerated. Once they are accused of unruly practices that prevent them from staying in their subservient place, they threaten the natural order of things.

A speculative mode of thinking with borders as multispecies matters of care not only avoids re-iterating naturalised images and imaginations of pureness, but also brings to the fore relations to the environment, the earth, and the soil which are not rooted in the concept of the nation, nativity, and kinship as supposed matters of fate. Even though it is imperative not to equalise the situation and difficulties human refugees are facing with the problems other species have, their struggles and stories are sometimes interconnected, for the better or worse. Feminist scholars and scholars of colour have demonstrated that the history of Western thought is full of equations between racialised, colonised, and Othered people and nonhuman life that has served to establish and reinforce a presumed inferiority of both. Nevertheless, in line with Astrida Neimanis, we believe that it is important 'to recognize the way' violence against people marked as the Other and nonhuman life is often 'intimately imbricated and part of the "master model" of domination' (Neimanis 2015, 143). Likewise, it should not be left unmentioned that the category of species, too, constitutes violence not only against nonhumans but also against Othered humans. Feminist scholars and scholars of colour have demonstrated that, as a hierarchical and naturalised category, species is closely tied to race and sex. For Haraway $(2008,18)$, for example, the

discursive tie between the colonized, the enslaved, the noncitizen, and the animal - all reduced to type, all Others to rational man, and all essential to his bright constitution - is at the heart of racism and flourishes, lethally, in the entrails of humanism.

Haraway not only urges us to remain alert to the category of species but also highlights the importance of untying this heritage wherever possible and replacing it with 'better knots'. $^{13}$

Instead of producing images and imaginations about nativity and territory, a feminist technoecological reading of borders shifts the focus on existential territories and on questions of kin through affinity and shared struggles, sensitising us to the multilayered and often neglected entanglements of human and nonhuman bodies that enact and are enacted by borders, shifting the focus to what we call feminist transversal solidarity as a theoretical approach as well as a radical political practice. 'We live in a time when it is not only animal species that are disappearing; so too are the words, expressions, and gestures of human solidarity', Guattari $(1989,135)$ argues. It is precisely for this reason, as this story illustrates, that solidarity and care for the other cannot be reduced to the human but have to be extended across multiple boundaries. From a feminist technoecological perspective on borders, therefore, the phrase for earthly survival today might very well be: 'Whoever is here, is from here'. ${ }^{14}$

\section{Naturalising geologies, territories, and bodies}

In January 2010, while working as a counsellor for refugees in an NGO in Vienna, Cumar, a former client of mine who travelled the year before from Somalia through Ethiopia and Libya to Italy, and from there to Austria, reported about the struggle his cousin Kaahin 
was facing in the UK. After Kaahin's sister as well as two of his elder brothers had already received asylum in the UK, Kaahin was the last member of the family to escape war-torn Somalia for a better life in Europe. However, by the time Kaahin was applying for asylum in the UK public debates on the abuse of the UK asylum system and worries about so-called 'nationality swapping' - that is, the accusation that refugees would tend to claim to come from war-torn regions, only to have better chances for receiving asylum in Europe - were dominating the media and politics. Eventually, these debates culminated in the call for developing 'appropriate measures in order to stop this abuse of the UK asylum system' (UK Border Agency 2009a, 3). As someone whose development as a scholar was shaped by the experience as a migrant, I could immediately relate to Cumar and those debates in different political, philosophical, and affective ways.

In the wake of debates on the alleged abuse of the asylum system, the UK Border Agency launched its Human Provenance Pilot Project in September 2009. Despite its name suggesting something different, the project did not aim at determining the provenance of humans as a species but rather targeted persons who were 'making false claims about their nationality when making their application for asylum' (UKBA 2009b), providing evidence for assessing whether or not applicants were telling the truth about their country of origin. Since the UK Border Agency considered so-called nationality swapping to be widely practiced, especially among African asylum seekers, the project solely targeted refugees from Africa, in particular, those stating to come from Somalia. As Somalia is regarded as a failed state - that is, as a state that cannot guarantee the basic rights of its citizens, chances for Somali refugees to receive asylum in the UK were high - as long as they could prove that they were indeed coming from Somalia.

Departing from the assumption that bodies cannot lie, the UK Border Agency's Human Provenance Pilot Project operated following the assumption that a combination of DNA ancestry testing - which involved Y-chromosome analysis, ${ }^{15}$ mitochondrial DNA analysis, ${ }^{16}$ and single-nucleotide polymorphisms tests - along with strontium isotope analysis would reveal the asylum applicant's 'true country of origin' (UKBA 2009b). Even though the UK Border Agency did not reveal any details about the isotopes under examination, the analysis of hair and skin tissue samples suggests that the tests focused on lighter element isotopes such as strontium (see Travis 2009). Strontium is a chemical element that is mostly found in inorganic materials such as rock. Through weathering strontium trickles into the ground water from where it makes its way into plants, animals, and the human body. Similar to calcium, strontium becomes embedded in bones, hair, and nail tissue. As the number of the particles in the atomic nucleus varies according to geographical location and the isotopes incorporated are in a constant exchange with the surrounding environment, examining the isotopic ratios in nail and hair tissue and matching them against comparison ratios from the country of which the asylum seeker claims to hold nationality, should have allowed the UK Border Agency to draw conclusions about the place of birth of the applicant. Initially, the UK Border Agency had planned to use genetic and isotope test results as definitive proof of the applicants' nationality. However, due to critique from the scientific community, ${ }^{17}$ the authorities decided not to rely solely on the test results in the evaluation process of individual applicants' cases. After two years the project was terminated in summer 2011. The announced final report was never published, the planned scientific review was suspended, and the UK Home Office (2011) said that it 
has no intentions of continuing the project in the near future, without providing any explanation for this decision.

Reading the story of UK Border Agency's Human Provenance Pilot Project speculatively through the lens of feminist technoecology means to consider the project - far from determining supposed truths about bodies and environments, in the sense of geological and political territories - as an attempt at enacting and naturalising bodies, boundaries, and territories alike. Functioning as a site where human and nonhuman bodies, technologies, technoscientific and other practices, as well as territories, politics, and laws, in their entanglement, intra-actively enact the very bodies, boundaries, and territories the project sought to measure, the Human Provenance Pilot Project can be understood as a multispecies matter of care where cuts that matter come to matter, along with far-reaching consequences. Not only the border became a fluid contact zone composed of human and nonhuman bodies, amongst other things, but also the bodies involved embodied the border. In an important sense, the UK Border Agency's Human Provenance Pilot Project did not so much mark or represent the border as it performatively hailed into being both particularly reconfigured borders and bodies. The bodies under investigation themselves became the border, as the isotopes incorporated in hair and nail, the mitochondria in the cells, and the chromosomes of the applicants were linked to particular geologies and territories, determining who belongs to a particular geographical place. Zoē was transformed into bios, bare biological life - such as the isotopes and mitochondria incorporated in the bodies of asylum applicants - became political life. These geomarkers - that is, particular geological and geochemical materials incorporated in bodies that refer to particular places or locations on the planet - not only were sought to link the biological body to political images and imaginations about ethnicity, kin, nationality, the environment, soil, and territory, but also to mark them in a very material sense, essentialising territories, boundaries, and bodies, in the very same movement. Nationality, for the UK Border Agency, became identical with nativity.

Giorgio Agamben reminds us that both the nation and the native share the same Latin root - namely, 'nationem' for 'that which has been born', demonstrating once again the etymological association of territories and borders with organisms. It has to be understood in this light that for Agamben the nation state,

means a state that makes nativity or birth [nascita] (that is, naked human life) the foundation of its own sovereignty. This is the meaning (and it is not even a hidden one) of the first three articles of the 1789 Declaration: it is only because this declaration inscribed (in articles 1 and 2) the native element in the heart of any political organization that it can firmly bind (in article 3) the principle of sovereignty to the nation (in conformity with its etymon, native [nation] originally meant simply "birth" [nascita]). The fiction that is implicit here is that birth [nascital] comes into being immediately as nation, so that there may not be any difference between the two moments. (Agamben 2000, 21)

It is precisely this link between nationality and nativity that the Human Provenance Pilot Project sought to reinforce - a link that is constantly threatened by migrants, particularly by undocumented ones, who "break the link between "nativity" and nationality and bring the nation-state system into crisis' (Khosravi 2010, 2).

Even though it is not new to link bodies to particular geological and political territories, until recently the marks were predominantly left on the surface of bodies - the colour of the skin, the shape of the body, etc. This is not to say that phenotype becomes 
unimportant but rather that phenomena such as the UK Border Agency's Human Provenance Pilot Project aimed at relocating the link between nativity and nationality, between kin and territory, into the very depths of the body. As the project sought to enact not only bodies marked by ethnicity and nationality, but also their corresponding environments, that is, geological and political territories, it aimed at actualising race and ethnicity as a geopolitical project that is enmeshed with the ideologies of capitalism and the nation station. Rather than charting borders as fixed lines on maps and reading off particular identities as supposed truths from bodies, it was only through the project that naturalised territories and allegedly authentic Somali bodies came into being bodies that mattered, and subsequently received asylum in the UK, and those that did not matter. Mitropoulos (2016) reminds us that if we think of the border 'as a site of invariant bodies moving across a divided but otherwise continuous space - then we begin by assuming, incorrectly, that the properties of bodies (or even "the subject") and the properties of space can be distinguished'. A speculative reading of the story of the Human Provenance Pilot Project through the diffractive lens of feminist technoecology suggests that rather than occupying a space in the environment, bodies and environments were intraactively constituted as borders themselves. What is more, considering the UK Border Agency's Human Provenance Pilot Project as a multispecies matter of care illustrates that the fact that borders have become ubiquities does not mean that the border is everywhere, but rather that every space-time point can potentially become the border for certain bodies, which then are not so much 'expelled by the border', as they are 'forced to be the border' (Khosravi 2010, 99).

Stacy Alaimo provides us with a powerful account of the body as a porous set of relations. With her concept of 'trans-corporeality', Alaimo $(2010,2)$ reworks human corporeality as 'always intermeshed with the more-than-human world'. Understanding bodies as transcorporeal not only means to understand them as 'inseparable from "the environment"', but also shifts the focus on 'the often unpredictable and unwanted actions of human bodies, nonhuman creatures, ecological systems, chemical agents, and other actors' (Alaimo 2010, 2). In the case of the UK Border Agency's Human Provenance Pilot Project, the porosity of bodies on a molecular level is demonstrated in the active capacities of the mitochondria and the isotopes incorporated in them. Far from only being inert biological or geological forces, both the mitochondria and the isotopes under investigation - as part of particular entanglements of technologies, bodies, discourses, environments, as well technoscientific and other practices - did something, entailing material and political consequences. Even though, ironically, it could be argued that the idea behind the UK Border Agency's Human Provenance Pilot Project was to acknowledge (and make use of) the active and generative potentials of both human and nonhuman bodies to incorporate and memorise geology and territory, what the project failed to take into account was failure itself, and the fact that bodies, too, are not passive receptors of geological forces and power relations. While it is true that isotopes might vary according to geographical location, and that they leave their marks on porous bodies, territory and nationality are political concepts, and hence something entirely different. The fact that the UK Border Agency's Human Provenance Pilot Project has not only received devastating critique from the scientific community but ultimately also failed in technoscientifically determining the ethnicity and nationality of the bodies under investigation demonstrates that however repressive borders might be, it does not mean that they are always effective, and 
their effects controllable and foreseeable. This is not to romanticise such immanent system failures. Nevertheless, the very possibility to take failure analytically into account might open up possibilities for grasping not only vulnerability but also potentiality in technoscientific and other contexts in order to cultivate care and solidarity. Similarly, and yet differently, as in the previous story, caring and solidarity manifests in the telling of the UK Border Agency's Human Provenance Pilot Project as an involved, situated story. Rather than observing from the distance, involved stories and involved knowledge are about 'being touched' (Puig de la Bellacasa 2017, 93) by something in a way that cultivates solidarity and care. Because they are involved and situated, these stories are never innocent, nor should the asymmetries of power that unfold in and around them be left unnoticed.

\section{Conclusions}

In this article, we introduced the concept of feminist technoecology as a diffractive lens for thinking with borders as multispecies matters of care. Instead of considering borders primarily as physical arrangements, we demonstrated how feminist technoecology as a speculative mode of thinking allows us to take into account borders as 'sites' where not only a division in an epistemological and social sense is introduced - insofar as social and cultural differences are established (see Mezzadra and Neilson 2013, 14; see also Nail 2016) - but also material cuts that leave marks on bodies and the earth are enacted. Étienne Balibar reminds us of the 'world-configuring function' (Balibar 2002, 79) of borders. For Balibar, borders 'perform', that is, they enact worldly consequences. Without this function, 'there would be no borders - or no lasting borders' (Balibar 2002, 79). It is in this very light that a technoecological take on borders radically breaks with an a-priori distinction between technology, ecology, geology, politics, bodies, and a more-than-human world by shifting the focus on the cuts and knots that make a difference in the process of bordering.

In order 'for more caring affective ecologies to become possible, we need speculative thinking' (Puig de la Bellacasa 2017, 219) as much as situated stories. Turning to two such stories of borders and reading them speculatively through the lens of feminist technoecology, we foregrounded how bordering marks a performative act in which not only humans take part. Drawing on feminist accounts of care and solidarity, we emphasised the need for a more inclusive form of solidarity and care. Inseparably tied to technoecology as a tool for speculative encounters with borders as multispecies matters of care, the concept of 'feminist transversal solidarity' answers this call by shifting the attention to the often neglected cuts borders enact that deeply affect not only humans but also a more-than-human world. In both stories presented, we demonstrated that caring is both a feminist practice of critique and 'a doing and ethico-political commitment that affects the way we produce knowledge about things' (Puig de la Bellacasa 2011, 100). ${ }^{18}$ These encounters with borders invite feminist and other critical scholars not only to rethink the porous boundaries between human and nonhuman bodies, ecosystems, geologies, and technologies in the context of border control and beyond, but also highlight the necessity for transversal solidarity. Encountering borders as multispecies matters of care, consequently, foregrounds an ethos of intervention in their un/becoming. It is for this reason that such an account aims at generating care and solidarity by 'counting in participants and issues who have not managed or are not likely to succeed in articulating their concerns, or 
whose modes of articulation indicate a politics that is "imperceptible"' (Puig de la Bellacasa 2011, 94-95). Taking in such a perspective, neglected things such as the shared struggles of human and nonhuman bodies at the border or the 'political life' of isotopes and geologies gain centre stage, demonstrating the need for solidarity and care across multiple boundaries. Understanding borders as multispecies matters of care for this reason boils down to intervening into the ethics and politics of processes of becoming-with as well as into the production of knowledge about borders, bodies, and boundaries in the making against the backdrop of today's multiple planetary crises.

\section{Notes}

1. See for a detailed discussion of the Proto-Indo-European roots of the notion of the border the etymological lexicon of the Dnghu Adsoqiation (2007); particularly page 496.

2. While Foucault's concept of biopolitics refers to the practices of appropriating and managing the flows and forces of living bodies as part of an imagined whole (the nation state) for the demands of the political economy, the concept of necropolitics (Mbembe 2003) shifts the focus on the practices through which certain bodies are abandoned or destined towards death. Rather than 'inscribing bodies within disciplinary apparatuses' (Mbembe 2003, 34), death itself consolidates sovereign power through the creation of death zones - such as, for example, refugee camps in Idomeni at the border between Macedonia and Greece or prison camps in Libya - where the sovereign power ceases to guarantee the right to live for everyone. Hence, necropolitics designates nothing less than 'the right to expose to death' (Mbembe 2003, 10).

3. The notion of diffraction has a rich feminist history. Despite that we employ diffraction as a lens that allows for a specific speculative mode of thinking, rather than as a method, we remain indebted to Donna Haraway's and Karen Barad's reframing of the physical phenomenon of diffraction as a feminist figure and method that allows for taking into account the 'patterns of difference that make a difference' (Barad 2007, 72). For diffraction as a methodology see Barad (2007) and van der Tuin (2014).

4. In The Three Ecologies, Guattari not only emphasizes that today, perhaps more than ever, 'nature has become inseparable from culture', but also that 'we have to learn to think "transversally"', if we want to understand how 'ecosystems, the mechanosphere, and the social and individual universes of reference', in their entanglement with one another, function (Guattari 1989, 135).

5. Feminist scholars have extensively discussed the work of Félix Guattari und Gilles Deleuze. Elizabeth Grosz, Clair Colebrook, and Rosi Braidotti, to name but a few, reworked key concepts and ideas in both affirmative and critical readings of Deleuze and Guattari's philosophy. For an overview see, for example, Buchanan and Colebrook (2000) and Stark (2017).

6. In 'The Rhetoric of Drugs', an interview from the year 1989, Jacques Derrida puts forward the argument that 'there is no natural, originary body: technology has not simply added itself, from the outside or after the fact, as a foreign body' (Derrida 1995, 244). Derrida not only seems to suggest that, rather than being the Other to the body, technology and the body are inextricably intertwined with one another but also that there is no such thing as a natural - that is to say, a technologically untouched - body.

7. In contrast to the notion of interaction, 'which presumes the prior existence of independent entities or relata' (Barad 2007, 139), Karen Barad's neologism of intra-action highlights that relata do not precede their relations. It is only through intra-actions that boundaries and properties materialise. Hence, the concept of intra-action troubles the very nature of dichotomies, that is, the idea and practice of cutting-apart. Intra-actions 'enact agential cuts which do not produce absolute separations, but rather cut together-apart (one move).' Intra-actions are about foldedness, multiplicities and differences that matter all the way down, as much as about the responsibilities and accountabilities that are going along with them. 
8. Donna Haraway reminds us that staying with the trouble means to produce earthly - both in the sense of earthbound and worldly - stories. For Haraway, stories are powerful contributions and contributors to the becoming of a shared world insofar as they reject an all too simple division between reality and fiction. Stories produce new connections and with them new responsibilities and accountabilities for what matters as well as for what is excluded from mattering. It is precisely in this light that Haraway emphasizes 'multispecies storytelling is about recuperation in complex histories that are full of dying as living, as full of endings, even genocides, as beginnings' (Haraway 2016a, 10).

9. In ecology, a variety of concepts and descriptions exist for understanding ecosystems. While the idea of ecosystems as being self-contained has been more and more challenged over the last few decades, particularly through ecological resilience approaches which emphasise the dynamic and entangled nature of ecosystems, invasion ecology often tends to hold onto the idea of ecosystems as defined by closure rather than by connectedness, and therefore as always threatened by potential invaders.

10. It is for this reason that it is important to note that 'invasion' as a concept operates from the differentiation between a seemingly clearly separable and definable inside and outside, an 'us' and 'them' is needed in order to evoke the fear of a hostile, invading Other that threatens a presumed homogeneity and integrity, and consequently the very existence of the self.

11. Dedicated to the study of the negative impacts of non-native species to domestic ecosystems, invasion ecology emerged in the 1950 s as a subdiscipline of ecology. For a critical take on invasion ecology see, for example, Pearce (2015).

12. In recent years many scientists have contested the concept of invasive species, arguing that in most cases alien species are not only not harmful to native species but, on the contrary, might even increase the biodiversity and the resilience of ecosystems (see Pearce 2015).

13. For a critical discussion of the species category in the context of invasion ecology see also Subramaniam (2001). A more affirmative take on species can be found, for example, in Elizabeth Grosz' feminist reading of Charles Darwin's work. We would like to thank one of the anonymous reviewers for reminding us of the manifold efforts undertaken by feminist scholars to problematize and deconstruct the species category.

14. The phrase 'Qui est ici est d'ici' was originally coined in the late 1990 s by French grassroots activists working for the rights of undocumented migrants.

15. Y line DNA tests look at specific markers on the Y-chromosome that are passed down paternal lines. This was also the reason why the project exclusively targeted male refugees. While sex and gender do not appear in the technical language of the project itself, as embodied categories they were both absent and present at the same time.

16. Mitochondrial DNA tests are used to scrutinise the genetic information stored in mitochondria. Mitochondria are organelles located in the cells of eukaryotic organisms which possess their own, independent genome.

17. See, for example, Nature $(2009,697)$.

18. Haraway reminds us that caring is always a doing and a knowing. Caring means 'becoming subject to the unsettling obligation of curiosity, which requires knowing more at the end of the day than at the beginning' (Haraway 2008, 36).

\section{Disclosure statement}

No potential conflict of interest was reported by the authors.

\section{Notes on contributors}

Josef Barla is a lecturer at the University of Vienna and an affiliated researcher with The Seed Box Environmental Humanities Collaboratory based at Linköping University in Sweden. Trained in the philosophy of technology and feminist epistemology, his research investigates how, against the 
backdrop of today's multiple planetary crises, questions of technology, ecology, (bio-) politics, and care, in their entanglement, are affecting the ways of living and dying well in the present and future.

Christoph Hubatschke is a DOC-Fellow of the Austrian Academy of Science. Currently, he is visiting research fellow at the Department for Visual Cultures, Goldsmiths University, London as well as PhDresearcher at the University of Vienna. His research focuses on the work of Gilles Deleuze, the philosophy of technology, political theory, new materialism and social movements.

\section{ORCID}

Josef Barla (iD) http://orcid.org/0000-0002-7506-0281

Christoph Hubatschke (D) http://orcid.org/0000-0002-1072-7081

\section{References}

Agamben, Giorgio. 2000. Means without End: Notes on Politics. Minneapolis: University of Minnesota Press.

Alaimo, Stacy. 2010. Bodily Natures. Science, Environment, and the Material Self. Bloomington and Indianapolis: Indiana University Press.

Balibar, Étienne. 2002. Politics and the other Scene. London: Verso.

Barad, Karen. 2007. Meeting the Universe Halfway. Quantum Physics and the Entanglement of Matter and Meaning. Durham, NC: Duke University Press.

Barbour, Michael G. 1996. "California Landscapes Before the Invaders." California Exotic Pest Plant Council. Accessed January 15, 2017. www.cal-ipc.org/symposia/archive/pdf/1996_symposium_ proceedings1837.pdf.

Buchanan, lan, and Claire Colebrook. 2000. Deleuze and Feminist Theory. Edinburgh: Edinburgh University Press.

Crosby, Alfred W. 1987. Ecological Imperialism: The Biological Expansion of Europe 900-1900. Cambridge: Cambridge University Press.

Deleuze, Gilles, and Félix Guattari. 1983. Anti-oedipus. Minneapolis: University of Minnesota Press.

Deleuze, Gilles, and Félix Guattari. 2004. A Thousand Plateaus. London: Continuum.

Derrida, Jacques. 1995. Points ...: Interviews 1974-1994. Edited by Elisabeth Weber. Stanford: Stanford University Press.

Dnghu Adsoqiation - Indo-European Language Association. 2007. Proto-Indo-European Etymological Dictionary. A Revised Edition of Julius Pokorny's Indogermanisches Etymologisches Wörterbuch. Badajoz: Indo-European Language Revival Association.

Elton, Charles S. 1958. The Ecology of Invasions. By Animals and Plants. London: Chapman and Hall.

Gould, Stephen Jay. 1998. "An Evolutionary Perspective on Strengths, Fallacies, and Confusions in the Concept of Native Plants." Arnoldia 58 (1): 3-10.

Guattari, Félix. (1964) 2015. "Transversality." In Psychoanalysis and Transversality, 102-120. Cambridge: Semiotext(e).

Guattari, Félix. 1989. "The Tree Ecologies." New Formations: A Journal of Culture/Theory/Politics 8:131-147. Haraway, Donna. 2008. When Species Meet. Bloomington: Indiana University Press.

Haraway, Donna. 2016a. Staying with the Trouble: Making Kin in the Chthulucene. Durham, NC: Duke University Press.

Haraway, Donna. 2016b. Manifestly Haraway. Minneapolis: University of Minnesota Press.

Jones, Reece. 2016. Violent Borders. Refugees and the Right to Move. London: Verso.

Khosravi, Shahram. 2010. 'Illegal' Traveller. An Auto-ethnography of Borders. Basingstoke: Palgrave.

Mbembe, Achille. 2003. "Necropolitics." Public Culture 15 (1): 11-40.

Mezzadra, Sandro, and Brett Neilson. 2013. Border as Method, or, the Multiplication of Labor. Durham, NC: Duke University Press.

Mitropoulos, Angela. 2016. "On Borders/Race/Fascism/Labour/Precarity/Feminism/etc." base 30:1, October 29. http://www.basepublication.org/?p=107. 
Nail, Thomas. 2016. Theory of the Border. Oxford: Oxford University Press.

Nature. 2009. "Editorial: Genetics without Borders." Nature 461: 697.

Neimanis, Astrida. 2015. "No Representation Without Colonisation? (Or, Nature Represents Itself)." Somatechnics 5 (2): 135-153.

Neslen, Arthur. 2016. "Balkan Wildlife Faces Extinction Threat from Border Fence to Control Migrants." The Guardian, August 11. https://www.theguardian.com/environment/2016/aug/11/balkanwildlife-faces-extinction-threat-from-border-fence-to-control-migrants.

Pearce, Fred. 2015. The New Wild. Why Invasive Species Will be Nature's Salvation. London: Icon Books.

Puig de la Bellacasa, María. 2011. "Matters of Care in Technoscience: Assembling Neglected Things." Social Studies of Science 41 (1): 85-106.

Puig de la Bellacasa, María. 2012. "Nothing Comes without its World.' Thinking with Care." The Sociological Review 60 (2): 197-216.

Puig de la Bellacasa, María. 2017. Matters of Care. Speculative Ethics in More Than Human Worlds. Minneapolis and London: University of Minnesota Press.

Schlyer, Krista. 2012. Continental Divide: Wildlife, People, and the Border Wall. College Station: Texas A\&M University Press.

Stark, Hannah. 2017. Feminist Theory after Deleuze. London and New York: Bloomsbury.

Subramaniam, Banu. 2001. "The Aliens have Landed! Reflections on the Rhetoric of Biological Invasions." Meridians 2 (1): 26-40.

Travis, John. 2009. “Key Questions on Nationality Testing." Science Online, September 29. http://news. sciencemag.org/2009/09/key-questions-nationality-testing.

UK Border Agency. 2009a. "Nationality Swapping - Isotope Analysis and DNA Testing." Field Manual. Accessed December 12, 2011. http://news.sciencemag.org/scienceinsider/entry-assets/ nationality-swapping-DNA-testing.pdf.

UK Border Agency. 2009b. "Stakeholders Letter." September 11. Accessed December 12, 2011. http:// news.sciencemag.org/scienceinsider/entryassets/stakeholder\%2Bletter.11.9.09.doc.

UK Home Office. 2011. "FOI Release 20818 Human Provenance Pilot Project." Gov.UK, December 12. www.gov.uk/government/publications/20818-human-provenance-pilot-project.

van der Tuin, Iris. 2014. "Diffraction as a Methodology for Feminist Onto-epistemology: On Encountering Chantal Chawaf and Posthuman Interpellation." Parallax 20 (3): 231-244.

Yuval-Davis, Nira. 2006. "Human/Women's Rights and Feminist Transversal Politics." In Global Feminism: Transnational Women's Activism, Organizing, and Human Rights, edited by Myra Marx Ferree and Aili Mari Tripp, 275-295. New York: New York University Press.

Yuval-Davis, Nira. 2010. "Theorizing Identity: Beyond the 'Us' and 'Them' Dichotomy." Patterns of Prejudice 44 (3): 261-280. 